\title{
Acute Kidney Injury Reduces Phagocytic and Microbicidal Capacities of Alveolar Macrophages
}

\author{
Reinaldo C. Silva ${ }^{a}$ Maristella A. Landgraf ${ }^{b, c}$ Matheus Corrêa-Costa ${ }^{c}$ Patricia Semedo ${ }^{a}$ \\ Marcos A. Cenedeze ${ }^{a}$ Alvaro Pacheco-Silva ${ }^{a}$ Richardt G. Landgraf ${ }^{b, d}$ Niels O. S. Câmara ${ }^{a, c, d}$ \\ aLaboratório de Imunologia Clínica e Experimental. Disciplina de Nefrologia,Universidade Federal \\ de São Paulo, São Paulo; 'Laboratório de Inflamação e Farmacologia Vascular, Instituto de Ciências \\ Ambientais, Químicas e Farmacêuticas, Universidade Federal de São Paulo-Campus Diadema, São \\ Paulo; 'Laboratorio de Imunobiologia do Transplante, Departamento de Imunologia, Instituto de \\ Ciências Biomédicas, Universidade de São Paulo, São Paulo, SP; ${ }^{\mathrm{d} B o t h}$ authors contributed equally
}

\section{Key Words}

Alveolar macrophages • Pulmonary inflammation • Killing • Klebsiella pneumonia • Ischaemia and reperfusion injury

\begin{abstract}
Background/Aims: Renal ischaemia-reperfusion injury (IRI) is a systemic inflammatory process in which Th1 responses predominate affecting other organs including the lungs. The present study explored the phagocytic and microbicidal capacity of macrophages in rats with lung inflammation that underwent IRI. Methods: The alveolar macrophages of rats sensitised to OVA were evaluated for phagocytosis and bacterial killing $24 \mathrm{~h}$ after antigen challenge in animals with or without prior submission to $60 \mathrm{~min}$ of renal ischaemia. Results: Bronchoalveolar lavage had a high level of cellular infiltrate in immunised animals (420\%) compared with control animals; IRI significantly reduced this infiltration (52\%). Macrophages from animals immunised and challenged with OVA presented a 10x increase in phagocytic capacity compared to the control group, whereas immunised animals subjected to IRI showed a reduction in the phagocytic index of $68 \%$. The killing of Klebsiella pneumoniae by macrophages from immunised animals was higher (56\%) compared with the control group but reduced in animals submitted to IRI (45\%). Immunised and challenged group showed an increase in gene expression levels of IL-10(450\%), HO-1 (259\%), INF- $\gamma(460 \%)$ and MCP-1 (370\%) compared to the immunised group subjected to IRI. Conclusions: Renal ischaemia and reperfusion injury apparently alters the phagocytic and microbicidal capacity of macrophages, reducing lung inflammation to OVA.
\end{abstract}




\section{Introduction}

Several types of cells can contribute to the lung defence system, including structural cells, such as epithelial cells and fibroblasts, resident macrophages (alveolar macrophages) and haematopoietic cells that migrate into the lung. Among these cells, itinerant leukocytes, such as neutrophils, dendritic cells, lymphocytes and macrophages, can play an important role in the local immune response [1].

Macrophages are classically associated with a variety of activities, including the induction of inflammation, engulfment of microorganisms and dead cells, antigen presentation and the regulation of extracellular components. Alveolar macrophages also produce and secrete inflammatory cytokines, chemokines and lipid mediators, playing an important role in pulmonary innate immunity [2,3]. Alveolar macrophages also play an important role in the reduction of microorganisms in pulmonary inflammation [4]. The phagocytosis of opsonised particles is triggered by the interaction of opsonins with specific receptors on the surface of phagocytes. One of the most important and well-studied phagocytic receptors is the Fc $\gamma$ receptor ( $\mathrm{F} \gamma \mathrm{R} \mathrm{R})$, which binds to the Fc portion of immunoglobulins (Ig) that coat the target [5]. In this sense, efficient phagocytosis is achieved by opsonisation of the targets by Ig and complement proteins $[6,7]$.

Acute kidney injury (AKI) is characterised by an abrupt decline in renal function, resulting in the inability of the kidneys to perform their basic functions of excretion and maintenance of fluid and electrolyte homeostasis in the organism [8, 9]. Ischaemia-reperfusion injury (IRI) is one of the major causes of AKI. The pathogenesis of renal IRI is complex and not yet completely understood, but the inflammatory response is now accepted as an important pathogenic component, such as endothelial injury and reactive oxygen species (ROS) [10,11]. Patients with AKI have a higher incidence of complications, such as respiratory failure [12]. In mice and rats, after ischaemic AKI, lung injury characterised by neutrophil infiltration, pulmonary oedema and increased chemokine and cytokine expression can be observed [1315]. AKI can cause increased pulmonary permeability, pulmonary oedema and increased pulmonary neutrophil recruitment, all of which are consistent with acute lung injury.

Although there are several mechanisms through which AKI could lead to lung injury, little is known about the effects of AKI on the mechanism of immune response in the lungs. In this paper, we analyse the effects of systemic AKI in the function of alveolar macrophages during antigen-driven lung inflammation.

\section{Materials and Methods}

\section{Animals}

Eight- to twelve-week-old male Wistar rats (250-300 g) from our colony were housed in a $22 \pm 1^{\circ} \mathrm{C}$ environment at $60 \%$ humidity and maintained on a 12-h light-dark cycle with food and water provided ad libitum. All procedures used in this study were approved and performed in accordance with guidelines established by the Brazilian College of Animal Experimentation (COBEA) and approved by the Biomedical Sciences Institute/USP-Ethical Committee for Animal Research (CEEA).

\section{Immunisation protocol}

Rats were sensitised on days 0 and 7 by an intraperitoneal injection of a mixture containing $50 \mathrm{mg}$ of ovalbumin and $1 \mathrm{mg}$ of $\mathrm{Al}(\mathrm{OH}) 3$ in saline (a total volume of $0.7 \mathrm{ml}$ ). At 14 days after the first immunisation, the animals were challenged by exposure to an aerosol of ovalbumin (grade III, Sigma) generated by an ultrasonic nebuliser (ICEL US-800, SP, Brazil) delivering particles of 0.5-10 $\mu \mathrm{m}$ diameter at approximately $0.75 \mathrm{ml} / \mathrm{min}$ for $20 \mathrm{~min}$. The concentration of ovalbumin in the nebuliser was $2.5 \%(\mathrm{w} / \mathrm{v})$. The control group consisted of animals immunised as described and challenged with saline solution or non-immunised animals challenged with OVA aerosol as above. 


\section{Experimental model of IRI}

Surgery was performed 24 hours after the OVA challenge. Rats were anesthetised with ketaminexylazine (Agribrands do Brazil, São Paulo, Brazil). A midline incision was made, and both renal pedicles were cross-clamped. In the ischaemia period, animals were kept well hydrated with saline and at a constant temperature $\left(37^{\circ} \mathrm{C}\right)$ through a heating pad device. Sixty minutes later, the microsurgery clamps were removed, the abdomen was closed in two layers, and the animals were placed in single cages and warmed by indirect light until complete recovery from anaesthesia. Control rats were subjected to the surgical procedure without clamping of renal pedicles (sham animals). The animals were kept under adjustable conditions until sacrifice 24 hours after reperfusion.

\section{Analysis of renal function}

Serum creatinine was used for the evaluation of renal function after IRI. Blood samples were collected 24 hours after ischaemic surgery from the abdominal inferior cava vein immediately before induced death. Serum creatinine levels were determined through absorbance readings at $520 \mathrm{~nm}$ with a spectrophotometer using a modified Jaffé technique.

\section{Bronchoalveolar lavage}

The animals were anesthetized with an injection of ketamine/xylasine $24 \mathrm{~h}$ after ischaemia or sham surgery. A tracheal cannula was inserted via a midcervical incision, and the airways were flushed five times with $10 \mathrm{ml}$ of phosphate-buffered saline (PBS, pH 7.4 at $4^{\circ} \mathrm{C}$ ).

\section{Total and differential cell counts}

Bronchoalveolar lavage (BAL) fluid was centrifuged at $170 \mathrm{~g}$ for $10 \mathrm{~min}$ at $4^{\circ} \mathrm{C}$, the supernatant was removed, and the cell pellet was resuspended in $0.5 \mathrm{~mL}$ of PBS. One volume of a solution containing $0.5 \%$ crystal violet dissolved in $30 \%$ acetic acid was added to nine volumes of the cell suspension. The total number of cells was determined by counting in a hematocytometer. Differential cell counts were performed after cytocentrifugation and staining with haematoxylin-eosin (Hema 3).

\section{Cell isolation and culture}

Resident macrophages were obtained from rats via ex vivo lung lavage, as previously described [3], and resuspended in RPMI-1640 (Gibco-Invitrogen, Carlsbad, CA) to a final concentration of $2 \times 10^{5}$ cells $/ \mathrm{mL}$. The cells were allowed to adhere to culture plates for 1 hour $\left(37^{\circ} \mathrm{C}, 5 \% \mathrm{CO} 2\right)$ followed by one wash with warm RPMI-1640. More than $99 \%$ of the adherent cells were identified as alveolar macrophages according to a modified Wright-Giemsa stain. Cells were cultured overnight in RPMI-1640 supplemented with $2 \%$ fetal bovine serum (FBS) and washed twice with warm medium to remove non-adherent cells.

Phagocytosis of red blood cells opsonised with IgG and evaluation of the phagocytic index.

Red blood cells (Bioboavista Laboratories, Brazil) were opsonised with a subagglutinating concentration of IgG rabbit anti-sheep erythrocyte antibody (IgG-RBCs) (Cappel Organon Teknika, Durham, NC) as previously described [16]. The phagocytosis of lamb red blood cells by rat alveolar macrophages was evaluated according to a method previously described by Aronoff et al. [17]. Briefly, $2 \times 10^{5}$ cells were added to each well of a 24-well culture plate and allowed to adhere for 1 hour $\left(37^{\circ} \mathrm{C}, 5 \% \mathrm{CO}_{2}\right)$. The cell monolayer was washed to remove non-adherent cells and then cultured for 18 hours in RPMI containing $2 \%$ fetal bovine serum (HyClone, Logan, UT-USA), according to Serezani et al. [3].

The alveolar macrophages were washed with PBS at $37^{\circ} \mathrm{C}$ and incubated with or without LTC4 (100 nM) (Biomol Inc., Palo Alto, CA-USA) for 10 minutes. Following the incubation, the supernatant was removed, and blood cells that were opsonised or not opsonised (internalisation control) were added to the alveolar macrophages at a concentration ratio of 50:1. The samples were incubated for $90 \mathrm{~min}$ at $37^{\circ} \mathrm{C}$ and $5 \% \mathrm{CO}_{2}$ in PBS. After phagocytosis, the cells were washed three times with PBS and stained with haematoxylin and eosin. The phagocytic index (PI), which was derived by multiplying the percentage of positive macrophages (alveolar macrophages containing at least one ingested target) by the mean number of phagocytised targets per positive macrophage, was determined by optical microscopy (x1000). 
Bacterial killing assay

Klebsiella pneumoniae 43816 serotype 2 was obtained from the American Type Culture Collection (ATCC, Rockville, MD). Bacterial stocks were thawed, inoculated into broth, and grown to log phase. The internalisation and intracellular killing of $K$. pneumoniae was monitored using a modification of the assay described by Bidani et al. [18]. Briefly, $2 \times 10^{5}$ macrophages were suspended in RPMI and infected with $K$. pneumoniae at a concentration ratio of $30: 1$ bacteria per cell at $37^{\circ} \mathrm{C}$ for $1 \mathrm{~h}$. The cell suspensions were centrifuged ( $\left.300 \mathrm{xg}, 10 \mathrm{~min}, 4^{\circ} \mathrm{C}\right)$, the supernatants were collected, and the cells were washed twice in PBS and lysed. Quantitative bacterial cultures were performed for the supernatants and cell lysates to determine the colony-forming units (CFUs) in the extracellular and intracellular environments. CFUs were determined by serial dilution on agar plates. $K$. pneumoniae was grown in BBL brain heart infusion broth and nutrient agar (DIFCO; Becton Dickinson) and incubated at $37^{\circ} \mathrm{C}$ for $18-24 \mathrm{~h}$.

\section{Measurement of nitric oxide}

To evaluate nitric oxide (NO) production, the nitrite concentrations in the supernatants of the alveolar macrophage cultures were measured using the standard Griess reaction. Briefly, $50 \mu \mathrm{l}$ of supernatant culture medium was added to $50 \mu \mathrm{l}$ of Griess reagent [equal volumes of $1 \%(\mathrm{w} / \mathrm{v})$ sulphanilamide in $2.5 \%$ $(\mathrm{v} / \mathrm{v})$ phosphoric acid and $0.1 \%(\mathrm{w} / \mathrm{v})$ naphthylenediamine- $\mathrm{HCl}]$ and incubated at room temperature for 10 min. The absorbance at $540 \mathrm{~nm}$ was then measured in a microplate reader (MultiskanEX), and the nitrite concentration was calculated based on a standard curve of sodium nitrite. All assays were performed in triplicate.

\section{Cytokine gene profiles}

Lung samples were quickly frozen in liquid nitrogen. Total RNA was isolated from lung tissue using TRIzol Reagent (Invitrogen, USA), and the RNA concentration was determined by absorbance readings in a spectrophotometer at $260 \mathrm{~nm}$ and $280 \mathrm{~nm}$. First-strand cDNA was synthesised using MML-V reverse transcriptase (Promega, USA). All experimental protocols for real-time PCR were based on the manufacturer's recommendation using the TaqMan gold RT-PCR Core Reagents Kit (PerkinElmer/Applied Biosystems). Primers and probes were purchased from Applied Biosystems. Cycling conditions were as follows: $10 \mathrm{~min}$ at $95^{\circ} \mathrm{C}$ followed by 45 cycles of $15 \mathrm{~s}$ at $95^{\circ} \mathrm{C}$ and $1 \mathrm{~min}$ at $60^{\circ} \mathrm{C}$. The amount of the target gene was first normalised to an endogenous reference (HPRT) and then normalised relative to a calibrator (sample with the lowest expression, namely, sham-operated animals) using the $2^{-\Delta \Delta c t}$ method. Therefore, steady-state mRNA levels were expressed as an $n$-fold difference relative to the calibrator. Analyses were performed with Sequence Detection Software 1.9 (SDS).

\section{Statistical analysis}

The data are expressed as the means \pm S.E.M. Statistical evaluation of the data was carried out by an analysis of variance (ANOVA), and the sequential analysis of differences among means was performed by Tukey's contrast analysis. A P value less than 0.05 was considered to be significant. $\mathrm{P}<0.05, \mathrm{P}<0.01$ and $\mathrm{P}<0.001$ are indicated with one, two and three asterisks, respectively. All of the experiments were independently performed at least three times.

\section{Results}

\section{Renal dysfunction}

Rats were subjected to 60 minutes of renal ischaemia. After $24 \mathrm{~h}$ of reperfusion, blood was collected to evaluate renal function by measuring serum creatinine and urea levels. The ischaemic group showed increased serum creatinine levels compared to the controls (sham animals) $(2.503 \pm 0.39$ vs. $0.776 \pm 0.07 \mathrm{mg} / \mathrm{dl})$. Serum creatinine levels were also increased in the ischaemic immunised group; however, these levels were not different from the IRI group. Similar results were observed in the urea levels (Fig. 1A and B). 

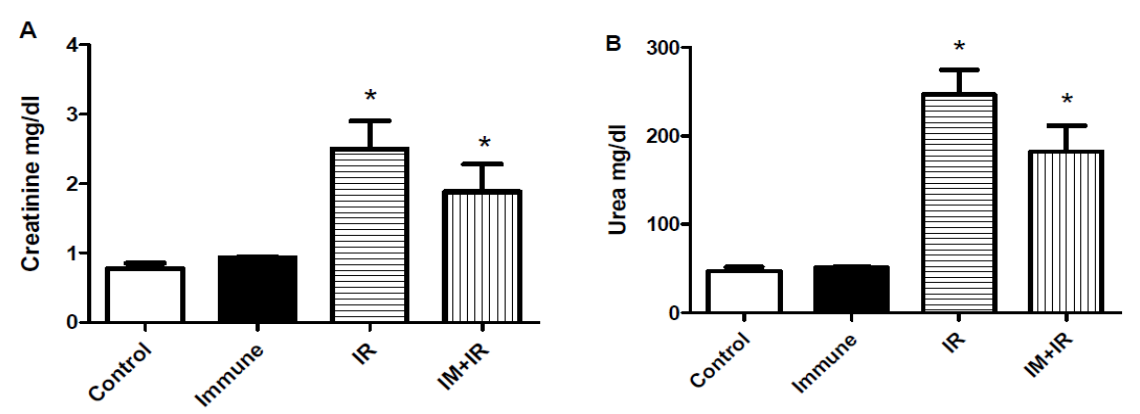

Fig. 1. Creatinine and urea levels in animals subjected to renal ischaemia and reperfusion (I/R). Animals subjected to I/R were assessed after $24 \mathrm{~h}$ of reperfusion. The results represent the mean \pm S.E.M of 6 animals per group, ${ }^{*} \mathrm{p}<0.001$ in comparison with the control group.

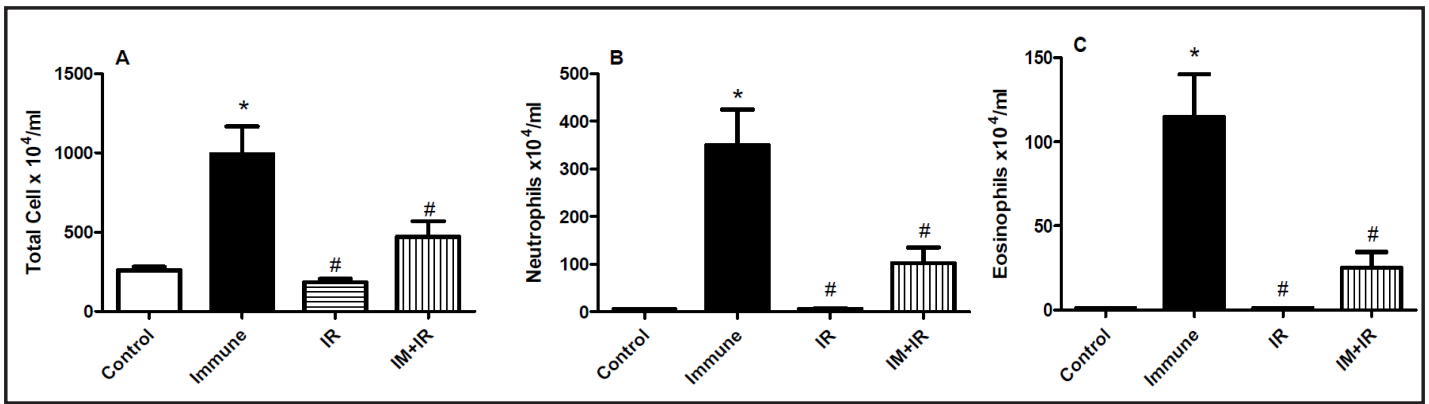

Fig. 2. Effect of I/R on bronchoalveolar lavage cells. Bronchoalveolar lavage was performed $24 \mathrm{~h}$ after I/R. Eosinophils and neutrophils were counted in a cytocentrifuged preparation of bronchoalveolar lavage cells stained with haematoxylin/eosin. The results are the mean \pm S.E.M of 5 animals per group. ${ }^{*} \mathrm{P}<0.01$ in comparison with the control group, and \# $\mathrm{P}<0.05$ in comparison with the immune group.

\section{Cells in BAL after IRI}

Immunised rats were challenged with ovalbumin and submitted to IRI $24 \mathrm{~h}$ later. Bronchoalveolar lavage was performed $24 \mathrm{~h}$ after surgery. The control group consisted of immunised and saline-challenged rats.

Although the number of eosinophils and neutrophils in the BALF of the control group was low (less than $1 \mathrm{cell} / \mathrm{ml}$ ), significant increases in total cells $(260.7 \pm 21.6$ to $994.3 \pm 172.4$ cells $\left.\times 10^{4} / \mathrm{ml}\right)$, neutrophils $\left(5.9 \pm 0.5\right.$ to $349.7 \pm 74.8$ cells $\left.\times 10^{4} / \mathrm{ml}\right)$ and eosinophils $(0.5 \pm 0.2$ to $114.9 \pm 25$ cells $\times 10^{4} / \mathrm{ml}$ ) were observed in the immunised and antigen-challenged rats (Fig. 2A, B and C). Figures 2A, B and C show the significantly decreased number of total cells (47\%), neutrophils (30\%) and eosinophils $(21 \%)$ in the BALF of immunised rats subjected to IRI.

\section{Effect of IRI on alveolar macrophage phagocytosis}

Eight hours after the incubation of red blood cells with AMs from sensitised rats, a significant increase in phagocytosis via Fc $\gamma \mathrm{R}$ was observed $(247 \pm 35.4$ to $826.5 \pm 91.6$ versus the control group), which persisted at high levels until $48 \mathrm{~h}(247 \pm 35.4$ to $1649 \pm 107.3$ versus the control group) (Fig. 3A). The immunised and sensitised rats showed an increase in phagocytosis compared to the control group $(247.0 \pm 35.4$ to $2875 \pm 217)$. Sensitised rats subjected to IRI showed decreased AM phagocytosis (2875 \pm 217 to $924.9 \pm 66.1$ ), as shown in Fig. 3B. 


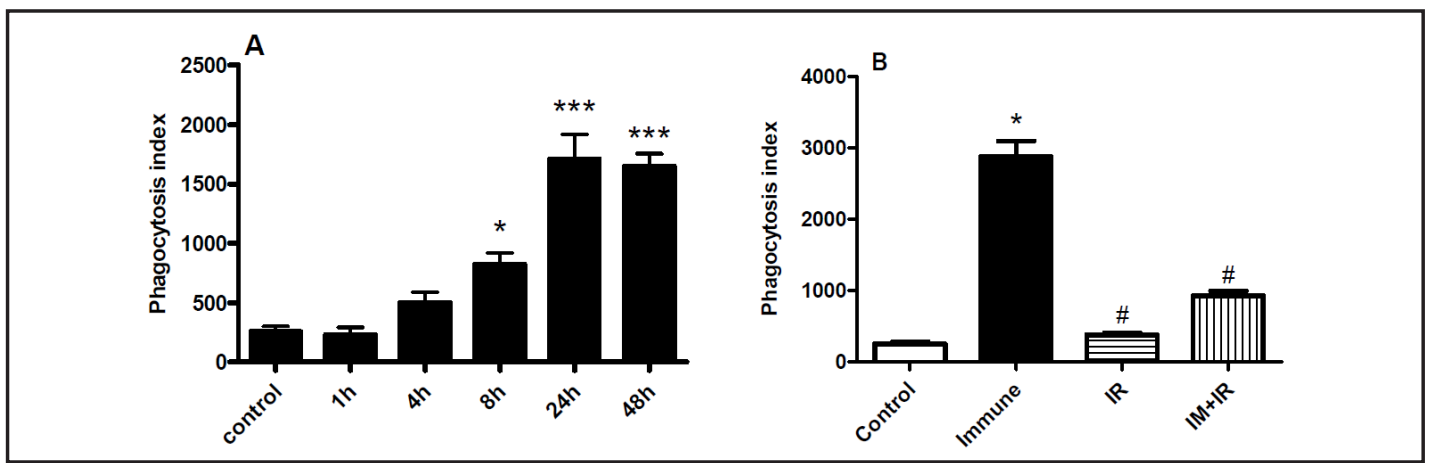

Fig. 3. Phagocytosis assay of red blood cells opsonised with IgG and evaluation of the phagocytic index. Resident macrophages from male Wistar rats were obtained by ex vivo bronchoalveolar lavage $24 \mathrm{~h}$ after I/R injury. (A) AMs from sensitised rats demonstrated a significant increase in phagocytosis via Fc $\gamma$ R, which persisted up to $24 \mathrm{~h}$. (B) I/R reduced the rate of AM phagocytosis in the immunised group. The results represent the mean \pm S.E.M. of 5 animals per group. ${ }^{*} \mathrm{P}<0.01$ compared with the control group, and \# $\mathrm{P}<$ 0.05 compared with the immunised group.

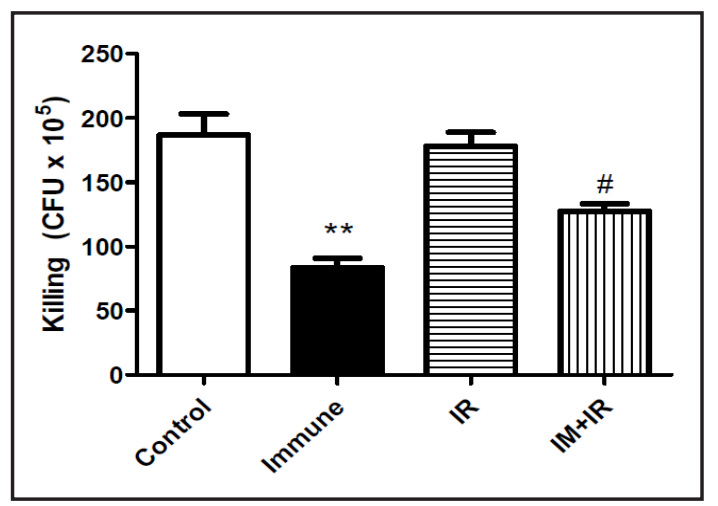

Fig. 4. Killing of Klebsiella pneumoniae by alveolar macrophages after AKI. AMs were infected with $K$. pneumoniae in vitro. After 3 hours, the macrophages were removed by scraping, and aliquots were cultured to determine the number of viable organisms by quantitative culture. The results represent the mean \pm S.E.M. of 5 animals per group. * $\mathrm{P}<0.01$ compared with the control group, and \# $\mathrm{P}<0.05$ compared with the immunised group.

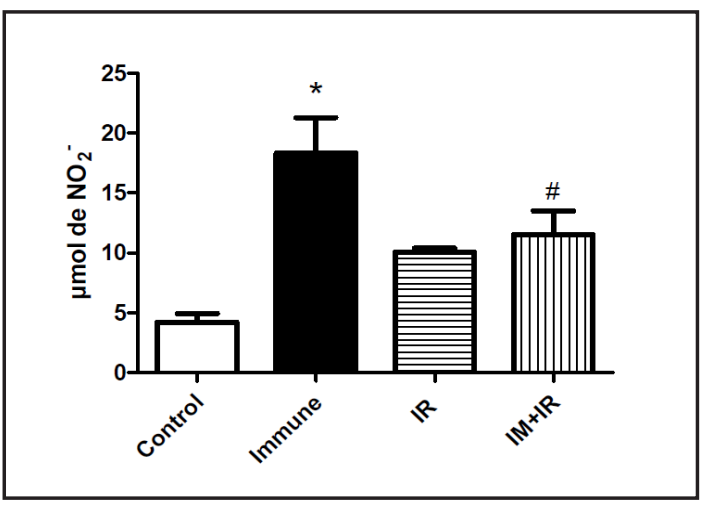

Fig. 5. Production of nitric oxide in cell culture supernatants. Nitric oxide production was measured using the Griess colorimetric reaction following the addition of sheep red blood cells (SRBCs) to AMs. The results represent the mean \pm S.E.M. of 6 animals per group. ${ }^{*} \mathrm{P}<0.001$ compared with the control group, and \# $\mathrm{P}<0.01$ compared with the immunised group.

\section{Effect of IRI on macrophage killing and nitric oxide generation}

The rate of killing internalised bacteria was increased in AMs from sensitised rats (187 \pm 16.2 to $87.6 \pm 7.2 \mathrm{CFU} \times 10^{5}$ ); however, AMs from sensitised rats subjected to IRI showed decreased killing ( $87.6 \pm 7.2$ to $127.3 \pm 6.1 \mathrm{CFU} \times 10^{5}$ ) (Fig. 4).

The culture supernatant of macrophages from sensitised rats showed increased nitric oxide generation compared to the control group $\left(4.2 \pm 0.7\right.$ to $\left.18.3 \pm 2.9 \mu \mathrm{mol} \mathrm{NO}_{2}{ }^{-}\right)$. However, the macrophages of rats with AKI showed significantly reduced nitric oxide production in the culture supernatant ( $18.3 \pm 2.9$ to $11.5 \pm 1.9 \mu \mathrm{mol} \mathrm{NO}_{2}{ }^{-}$) (Fig. 5).

\section{Cytokine expression}

Analysing the immune response and the concentrations of cytokines, we evaluated the mRNA expression of cytokines in the lung tissue of rats. We observed a significant increase in MCP-1 $(9.3 \pm 3.2$ to $2.2 \pm 1.6)$ and IFN- $\gamma(2.6 \pm 1.2$ to $0.3 \pm 0.04)$ in animals with pulmonary 
Fig. 6. Gene expression of cytokines present in lung tissue. Gene expression of MCP-1 (A), IFN $\gamma(B)$, IL-6 (C) and TNF (D) in lung tissues of animals subjected to I/R. The data are expressed as the mean of $2{ }^{\Delta \Delta} \mathrm{Ct} \pm \mathrm{SD}$ of 6 rats per group. * $\mathrm{p}<0,01$ compared with the IM+I/R group.

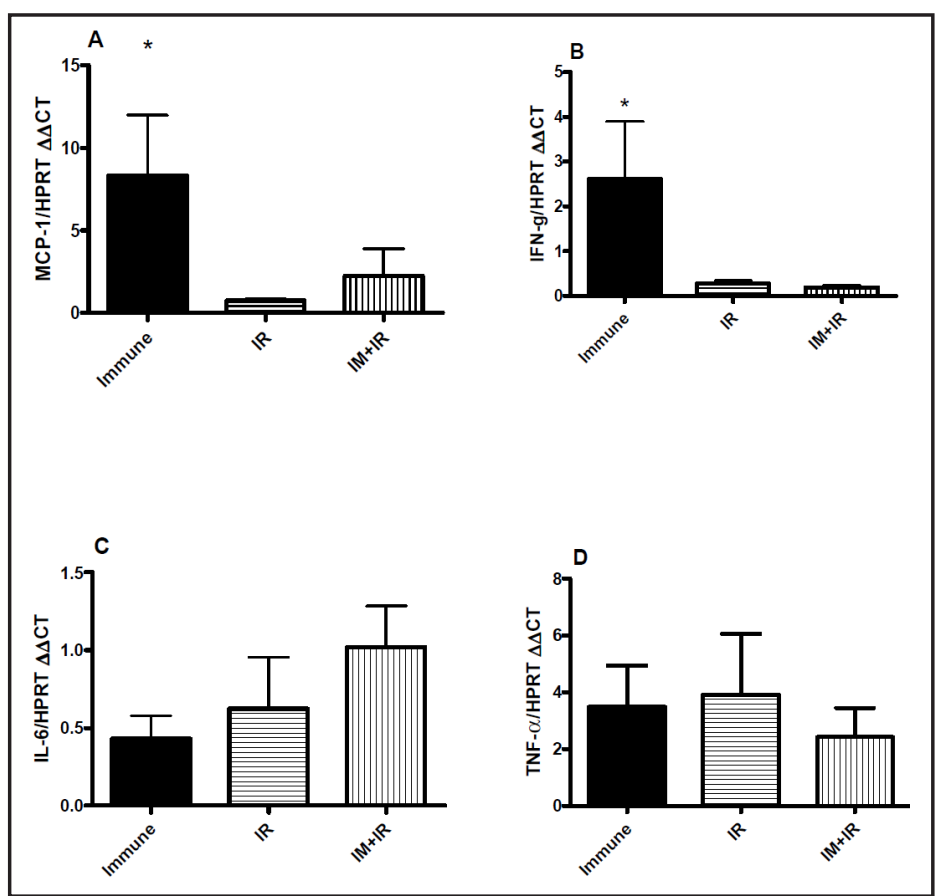

inflammation, but when these animals were subjected to IRI, we observed a significant reduction of MCP-1 and IFN- $\gamma$ (Fig. 6), without changes in IL-6 and TNF expression.

\section{Discussion}

Due to the constant presence of germs in the respiratory tract, an effective antimicrobial control system is extremely important to the host. In the periphery of the lungs, AMs attempt to control infections, maintain the sterility of the mucous and eliminate microorganisms on the surface of the alveoli through phagocytosis, microbicidal activity and the release of cytokines and bioactive lipids [19].

In this study, we evaluated the mechanisms through which alveolar macrophages participate in phagocytosis and killing through the Fc $\gamma$ receptor present in their membranes and the changes after secondary stimuli. We also evaluated the changes in rat lungs after the induction of allergic inflammation to ovalbumin and examined the role of alveolar macrophages in this process.

Wistar rats are usually used in allergic airway inflammation studies [4, 20, 21]. Furthermore, it has already been demonstrated the relationship between lung inflammation and ischemia-reperfusion injury in Wistar rats [22, 23].

Our data concerning the cellular infiltrate in the BAL of animals challenged with OVA confirm previous studies in the same model, demonstrating an increase in inflammatory cells, which is characteristic of the induction of allergic pulmonary inflammation, with a predominantly Th2 response pattern [24].

Acute respiratory distress syndrome and renal IRI frequently co-exist in patients in intensive treatment units, and this combination is associated with higher mortality $[25,26]$.

Previous evidence from the literature has shown that distinct Th1-related pathologies could modulate the inflammatory response observed in asthma [27, 28]. Recently, our group demonstrated that renal IRI could also modulate lung function in a model of allergic inflammation in mice [13].

Our results showed that acute kidney damage can significantly alter the cellular infiltrate in immunised and challenged mice because the induction of renal ischaemia causes a reduction in the migration of cells to the lung tissue, primarily polymorphonuclear cells. 
These results corroborate our recent studies that show that IRI could down-regulate allergic lung inflammation in mice [13].

Studies on phagocytosis after stimulation with LPS or ovalbumin showed a significant increase in degraded lipid uptake by macrophages [29], apoptotic neutrophils [30], and increased phagocytosis of $K$. pneumoniae $[4,31]$. We demonstrated that the macrophages of rats sensitised and challenged with ovalbumin aerosol had an increased capacity of phagocytosis of IgG- and complement-opsonised targets to kill K. pneumoniae, and the induction of IRI in these animals significantly reduced the capacity of phagocytosis. A possible explanation for this result could be that after IRI induction, the animal showed reduced polymorphonuclear cell migration to the lung tissue and the consequent reduction of inflammatory mediators released by these cells, most likely by altering the Th1/Th2 balance. These findings corroborate our previous findings that the activation of alveolar

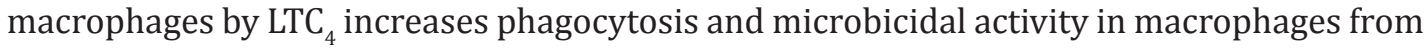
immunised and challenged rats [4].

The initial improvement in the inflammatory process is mediated by neutrophils and macrophages recruited to and activated at the site of injury [32]. Increased activity or a decrease in the population of these cells leads to an increased susceptibility to lung infection $[33,34]$. Our data indicate the increased survival of bacteria in alveolar macrophages from animals with an established pulmonary inflammation process and reduced cellular infiltration, primarily polymorphonuclear cells, after acute renal failure. These data suggest a greater resistance of the pathogen in the host, making these animals more susceptible to lung infection.

Circumstantial evidence suggests that the production of NO is part of an effective host response to infection and is stimulated by proinflammatory cytokines, such as IFN- $\gamma$, TNF- $\alpha$, and IL-2, and microbicidal products. The ability of AMs to produce NO with bactericidal effect has been shown in several clinical and experimental data $[35,36]$. Our data indicate that the greater "killing" ability observed in previously immunised and challenged rats could be related to the increased generation of NO by AMs from this group.

Initially, it was thought that the increase in IFN- $\gamma$ was associated with a reduction in allergic disease. However, subsequent studies showed that increased levels of IFN- $\gamma$ can be detected in the BAL of asthmatics [37]. In addition, T cells generating IFN- $\gamma$ can exacerbate airway inflammation in animal models [38]. The host response to pathogens is characterised by the infiltration of specific populations of leukocytes, including neutrophils and monocytes, into the injured tissue. This process is predominantly mediated by chemokines [39]. Among these cytokines, the CC chemokine family, including MCP- 1 and MIP-1 $\alpha$, have been implicated in the pathogenesis of chronic bronchitis [40, 41] and interstitial lung disease [42].

In a previous study, we demonstrated that IL-1 $\beta$, IL-2 and IL-12 expression was increased only in ischaemic mice, whereas IL-4, IL-5 and IL-13 were increased in immunised and challenged mice; however, in asthmatic mice subjected to renal IRI, the expression of Th2 cytokines was reduced to levels similar to that of ischaemic mice [13]. Some studies have demonstrated that the Th1 pattern in IRI is deleterious, while the Th2 pattern is protective $[43,44]$. Although we observed only a trend toward increased gene expression of TNF- $\alpha$ and IL-6 in animals with AKI after immunisation with OVA, these data suggest that the presence of these cytokines could modulate the inflammatory response, contributing to the less established activity of alveolar macrophages to eliminate invading microorganisms. This is because the pro-inflammatory molecules contribute to tissue damage, and anti-inflammatory mediators interfere with the host's ability to eliminate invading microorganisms.

In summary, our results show an influence of AKI in the inflammatory lung, modulating the cellular activity of alveolar macrophages and reducing their capacity of phagocytosis and pathogen killing. These results offer a new opportunity for understanding the mechanisms involved in the systemic effects of AKI, and its participation in the lung inflammatory response has been established. 
Silva/Landgraf/Corrêa-Costa et al.: Alveolar Macrophage Phagocytosis is Reduced by Kidney Injury

\section{Acknowledgements}

This work was supported by the Brazilian Foundation FAPESP (Fundação de Apoio à Pesquisa do Estado de São Paulo, grant numbers: 07/07139-3, 10/52180-4, 10/01404-0, 12/02270-0 and 12/51104-8), the International Associated Laboratory (CNPq/Inserm), INCT Complex Fluids and FADA-UNIFESP.

\section{References}

1 Suzuki T, Chow CW, Downey GP: Role of innate immune cells and their products in lung immunopathology. Int J Biochem Cell Biol 2008;40:1348-1361.

2 Miyake Y, Kaise H, Isono K, Koseki H, Kohno K, Tanaka M: Protective role of macrophages in noninflammatory lung injury caused by selective ablation of alveolar epithelial type ii cells. J Immunol 2007;178:5001-5009.

3 Serezani CH, Aronoff DM, Jancar S, Mancuso P, Peters-Golden M: Leukotrienes enhance the bactericidal activity of alveolar macrophages against klebsiella pneumoniae through the activation of nadph oxidase. Blood 2005;106:1067-1075.

- 4 Silva RC, Landgraf MA, Hiyane MI, Pacheco-Silva A, Camara NO, Landgraf RG: Leukotrienes produced in allergic lung inflammation activate alveolar macrophages. Cell Physiol Biochem 2010;26:319-326.

5 Ravetch JV, Bolland S: Igg fc receptors. Annu Rev Immunol 2001;19:275-290.

6 Aderem A, Underhill DM: Mechanisms of phagocytosis in macrophages. Annu Rev Immunol 1999;17:593623.

7 Flannagan RS, Cosio G, Grinstein S: Antimicrobial mechanisms of phagocytes and bacterial evasion strategies. Nat Rev Microbiol 2009;7:355-366.

8 Rana A, Sathyanarayana P, Lieberthal W: Role of apoptosis of renal tubular cells in acute renal failure: Therapeutic implications. Apoptosis 2001;6:83-102.

-9 Daher EF, Marques CN, Lima RS, Silva Junior GB, Barbosa AS, Barbosa ES, Mota RM, Leite da Silva S, Araujo SM, Liborio AB: Acute kidney injury in an infectious disease intensive care unit - an assessment of prognostic factors. Swiss Med Wkly 2008;138:128-133.

10 Bonventre JV, Zuk A: Ischemic acute renal failure: An inflammatory disease? Kidney Int 2004;66:480-485.

11 Molitoris BA, Sutton TA: Endothelial injury and dysfunction: Role in the extension phase of acute renal failure. Kidney Int 2004;66:496-499.

12 Levy EM, Viscoli CM, Horwitz RI: The effect of acute renal failure on mortality. A cohort analysis. Jama 1996;275:1489-1494.

13 Campanholle G, Silva RC, Martins JO, Landgraf MA, Paiva VN, Ferreira RR, Amano MT, Hiyane MI, Cenedeze MA, Pacheco-Silva A, Camara NO, Landgraf RG: Modulation of lung allergic response by renal ischemia and reperfusion injury. Cell Physiol Biochem 2012;29:523-532.

14 Hoke TS, Douglas IS, Klein CL, He Z, Fang W, Thurman JM, Tao Y, Dursun B, Voelkel NF, Edelstein CL, Faubel S: Acute renal failure after bilateral nephrectomy is associated with cytokine-mediated pulmonary injury. J Am Soc Nephrol 2007;18:155-164.

15 Deng J, Hu X, Yuen PS, Star RA: Alpha-melanocyte-stimulating hormone inhibits lung injury after renal ischemia/reperfusion. Am J Respir Crit Care Med 2004;169:749-756.

16 Araki N, Johnson MT, Swanson JA: A role for phosphoinositide 3-kinase in the completion of macropinocytosis and phagocytosis by macrophages. J Cell Biol 1996;135:1249-1260.

17 Aronoff DM, Canetti C, Serezani CH, Luo M, Peters-Golden M: Cutting edge: Macrophage inhibition by cyclic amp (camp): Differential roles of protein kinase a and exchange protein directly activated by camp-1. J Immunol 2005;174:595-599.

18 Bidani A, Reisner BS, Haque AK, Wen J, Helmer RE, Tuazon DM, Heming TA: Bactericidal activity of alveolar macrophages is suppressed by v-atpase inhibition. Lung 2000;178:91-104.

19 Gordon SB, Read RC: Macrophage defences against respiratory tract infections. Br Med Bull 2002;61:45-61.

20 Landgraf MA, Landgraf RG, Silva RC, Semedo P, Camara NOS, Fortes ZB: Intrauterine undernourishement althers Th1/Th2 cytokine balance and attenuate lung allergic inflammation in Wistar rats. Cell Physiol Biochem 2012;30:552-562.

21 Landgraf MA, Landgraf RG, Jancar S, Fortes ZB: Influence of age on the development of immunological lung response in intrauterine undernourishment. Nutrition 2008;24:262-269. 
22 Campos MR, Serezani CH, Peters-Golden M, Jancar S: Differential kinase requirement for enhancement of Fc gammaR-mediated phagocytosis in alveolar macrophages by leukotriene B4 vs. D4. Mol Immunol 2009;46:1204-1211.

23 Tripatara P, Patel NS, Webb A, Rathod K,Lecomte FM, Mazzon E, Cruzzocrea S, Yagoob MM, Ahluwalia A, Thiemermann C: Nitrite-derived nitric oxide protects the rat kidney against ischemia/reperfusion injury in vivo: role for xanthine oxidoreductase. J Am Soc Nephrol 2007;18:570-580.

24 Kramer AA, Postler G, Salhab KF, Mendez C, Carey LC, Rabb H: Renal ischemia/reperfusion leads to macrophage-mediated increase in pulmonary vascular permeability. Kidney Int 1999;55:2362-2367.

25 Rabb H, Wang Z, Nemoto T, Hotchkiss J, Yokota N, Soleimani M: Acute renal failure leads to dysregulation of lung salt and water channels. Kidney Int 2003;63:600-606.

26 Araujo MI, Lopes AA, Medeiros M, Cruz AA, Sousa-Atta L, Sole D, Carvalho EM: Inverse association between skin response to aeroallergens and schistosoma mansoni infection. Int Arch Allergy Immunol 2000;123:145-148.

27 Cardoso LS, Oliveira SC, Pacifico LG, Goes AM, Oliveira RR, Fonseca CT, Carvalho EM, Araujo MI: Schistosoma mansoni antigen-driven interleukin-10 production in infected asthmatic individuals. Mem Inst Oswaldo Cruz 2006;101:339-343.

-28 Quintero OA, Wright JR: Clearance of surfactant lipids by neutrophils and macrophages isolated from the acutely inflamed lung. Am J Physiol Lung Cell Mol Physiol 2002;282:L330-339.

29 Reidy MF, Wright JR: Surfactant protein a enhances apoptotic cell uptake and tgf-beta1 release by inflammatory alveolar macrophages. Am J Physiol Lung Cell Mol Physiol 2003;285:L854-861.

- 30 Hall NG, Liu Y, Hickman-Davis JM, Davis GC, Myles C, Andrews EJ, Matalon S, Lang JD Jr: Bactericidal function of alveolar macrophages in mechanically ventilated rabbits. Am J Respir Cell Mol Biol 2006;34:719-726.

-31 Toews GB, Gross GN, Pierce AK: The relationship of inoculum size to lung bacterial clearance and phagocytic cell response in mice. Am Rev Respir Dis 1979;120:559-566.

- 32 Nelson S, Summer WR: Innate immunity, cytokines, and pulmonary host defense. Infect Dis Clin North Am 1998;12:555-567, vii.

-33 Imanaka H, Shimaoka M, Matsuura N, Nishimura M, Ohta N, Kiyono H: Ventilator-induced lung injury is associated with neutrophil infiltration, macrophage activation, and tgf-beta 1 mrna upregulation in rat lungs. Anesth Analg 2001;92:428-436.

- 34 Anstey NM, Weinberg JB, Hassanali MY, Mwaikambo ED, Manyenga D, Misukonis MA, Arnelle DR, Hollis D, McDonald MI, Granger DL: Nitric oxide in tanzanian children with malaria: Inverse relationship between malaria severity and nitric oxide production/nitric oxide synthase type 2 expression. J Exp Med 1996;184:557-567.

35 Fang FC: Perspectives series: Host/pathogen interactions. Mechanisms of nitric oxide-related antimicrobial activity. J Clin Invest 1997;99:2818-2825.

36 Brown V, Warke TJ, Shields MD, Ennis M: T cell cytokine profiles in childhood asthma. Thorax 2003;58:311316.

37 Hansen G, Berry G, DeKruyff RH, Umetsu DT: Allergen-specific th1 cells fail to counterbalance th2 cellinduced airway hyperreactivity but cause severe airway inflammation. J Clin Invest 1999;103:175-183.

38 Proudfoot AE: Chemokine receptors: Multifaceted therapeutic targets. Nat Rev Immunol 2002;2:106-115.

-39 Barczyk A, Pierzchala W, Sozanska E: [levels of cc-chemokine (mcp-1 alpha, mip-1 beta) in induced sputum of patients with chronic obstructive pulmonary disease and patients with chronic bronchitis]. Pneumonol Alergol Pol 2001;69:40-49.

40 Capelli A, Di Stefano A, Gnemmi I, Balbo P, Cerutti CG, Balbi B, Lusuardi M, Donner CF: Increased mcp-1 and mip-1beta in bronchoalveolar lavage fluid of chronic bronchitics. Eur Respir J 1999;14:160-165.

-41 Yoshioka S, Mukae H, Sugiyama K, Kakugawa T, Sakamoto N, Nakayama S, Abe K, Fujii T, Kadota J, Kohno S: High-bal fluid concentrations of rantes in nonspecific interstitial pneumonia compared with usual interstitial pneumonia. Respir Med 2004;98:945-951.

-42 Marques VP, Goncalves GM, Feitoza CQ Cenedeze MA, Fernandes Bertocchi AP, Damiao MJ, Pinheiro HS, Antunes Teixeira VP, dos Reis MA, Pacheco-Silva A, Saraiva Camara NO: Influence of th1/th2 switched immune response on renal ischemia-reperfusion injury. Nephron Exp Nephrol 2006;104:e48-56.

43 Yokota N, Daniels F, Crosson J, Rabb H: Protective effect of t cell depletion in murine renal ischemiareperfusion injury. Transplantation 2002;74:759-763.

44 Ysebaert DK, De Greef KE, De Beuf A, Van Rompay AR, Vercauteren S, Persy VP, De Broe ME: T cells as mediators in renal ischemia/reperfusion injury. Kidney Int 2004;66:491-496. 